\title{
Identifying the Islam-Policies of the Predecessors of the Najib Administration: Has He Abandoned Tradition?
}

\author{
Osman Bakar
}

Since its political independence Malaysia has seen six Prime Ministers, including the present one, Dato' Sri Mohd Najib, who is himself a son of the second Prime Minister, Tun Abdul Razak. For a post-colonial Muslim state with a huge non-Muslim population (about 45 per cent) and an uninterrupted run of Westminsterstyle parliamentary democracy, six Prime Ministers in a total period of 54 years and, moreover, with a smooth line of succession, indicate a kind of political stability rarely found in the Islamic world. Malaysia is also noted for its relative success in managing its ethnic and religious plurality and diversity, especially when considering the fact that in its cultural makeup and setting ethnicity and religiosity are intricately linked.

A good number of factors have often been cited by observers of contemporary Malaysia to explain its political stability and interethnic and interreligious peace. These factors include a high literacy rate, a high standard of education of its citizens, and sound economic development. All these are, no doubt, acceptable explanatory factors. But there is yet another explanatory factor that has hardly ever been mentioned whenever people talk about the subject in question. This is the positive role of Islam in the public space. This factor is therefore closely related to yet another characteristic of post-colonial Malaysia, namely the state's increasingly active role in promoting Islam in the public space. It is with this characteristic that this Viewpoint is primarily concerned.

It is possible to make two related claims pertaining to the state's role in promoting Islam in Malaysian public space. My first claim is that each of Najib's predecessors is identifiable with what I call an 'Islam Policy'. As for Najib, we will treat his case separately since it is not quite clear that his Administration has an 'Islam Policy'. By an 'Islam Policy' I mean the policy adopted by the state to manage and promote the particular aspects of Islam singled out for development and emphasis, particularly in their communal and public dimensions.

The second claim, related to the first, is that each of the Islam policies has brought more good than harm to the country. I would further add that on the whole these Islam policies have been a contributing factor in Malaysia's political stability and interreligious peaceful coexistence. Looking back on these past policies with a critical eye we can see both their respective strengths and their weaknesses as well as their positive and negative impacts on Malaysian life. In view of the positive

* Osman Bakar is the Deputy CEO of IAIS Malaysia. 
impact far outweighing the negative one, it would be a pity if the Islam policy tradition were to be discontinued just in order to please its critics and opponents. But it would also be a mistake if the Islam policy tradition is to be continued just because its makers and implementers are claiming that the policies in place are nothing but good and beneficial for every citizen. What Malaysia needs is an enlightened and a just Islam policy that would address the legitimate needs of both the Muslim and the non-Muslim communities.

A re-examination of past Islamic policies is therefore called for with the view of improving upon them. In this Viewpoint, I would like to provide a brief overview of these policies. Tunku Abdul Rahman Putra, the first Prime Minister (1957-70), did not have a formal Islam policy. But despite his frequent portrayal of Malaysia as a 'secular country', his Administration did much in developing and expanding the religious institutions and bodies related to the five pillars of Islam. His government built many mosques throughout the country, including the National Mosque in Kuala Lumpur, to meet the Muslim community's needs for congregational prayer, an important feature of Islamic communal life. He introduced the national and international Qur'ān reading competitions to demonstrate the government's respect for the sanctity of Ramadan, the Muslim holy month of fasting. To help future pilgrims to Mecca invest their savings for the most important journey in their life the Tunku founded the Pilgrimage Fund Board (Lembaga Tabung Haji) which later grew to become a successful international corporation.

The most popular slogan used by the Tunku's official religious establishment was menegakkan shi'ar Islam, meaning 'upholding the symbols of Islam'. Mosques, the annual Qur'ân recital competition, the Pilgrimage Fund Board, and religious educational institutions were the most visible symbols of Malaysian Islam under the Tunku's rule. We could say that his Islam policy was none other than to project and dignify the symbols of Islam.

Tun Abdul Razak, the Tunku's successor as Prime Minister, had a formal Islam policy known as Penerapan nilai-nilai Islam dalam dasar negara dan pentadbiran awam ('Inculcation of Islamic values in national policies and public administration'). It has its origin in the political deal struck between UMNO and PAS in the aftermath of Malaysia's worst ethnic riots in its history in May 1969 and the Tunku's exit from political power. In 1974, Razak succeeded in bringing PAS into the newly created Barisan Nasional (BN, the National Front coalition government), a broad coalition of ethnic-based political parties. PAS under the leadership of Dato' Mohd Asri Haji Muda agreed to join the BN coalition on the condition that there would be an Islam policy with which it could identify itself and which its members could accept as a sufficient justification for the Party's entry into the coalition. Although its membership in the coalition was relatively brief PAS had the opportunity to put an Islamic stamp on a good number of the state programmes which in fact it utilised reasonably well. 
However broad the national and societal concern which a particular Islam policy may have, it may not by itself reveal the total picture of the state's relations or concern with Islam. It is possible that another national policy that is not termed 'Islamic' could have more repercussions for Islam and the Muslim community than the Islam policy itself. In the case of the Razak Administration its real significance for the state's relations with Islam lies in three other policy areas.

The first policy area pertains to the Rukunegara (National Ideology) which Razak proclaimed with the view of forging a new Malaysian identity out of its ethnic and religious pluralism. The second pertains to the New Economic Policy (NEP) which he launched to address the socio-economic imbalances among its ethnic groups, especially the deep grievances of the Malays. The third concerns his policy on political inclusivism aimed at representative government that would embrace practically all ethnic groups in the country and thus aimed at political stability. This policy resulted in the formation of the BN coalition that included PAS. The inclusion of PAS in the coalition had many consequences and implications for Islam and the Muslim community, especially for Malaysia's political Islam, which were to greatly influence the 'Islamic' transformation of Malaysia and to set in motion a progressively engaging relationship between Islam and the state. Never before has Malaysia seen in its years of independence a more politically united Muslim community than during the Razak Administration.

Razak's successor, Tun Hussein Onn, was not noted for any new Islam policy or national policy that was Islamically significant. He retained Razak's Islamic legacy but in a number of areas such as in da wah (propagation of Islam) and in religious institutional building his religious establishment tried to broaden and intensify the government's role. For example, Hussein launched the ' $d a$ 'wah month', a first in Malaysian history which saw the government religious bodies working closely with Muslim civil society groups with the objective of helping the people to better understand the teachings of Islam. The collaboration between the government and the non-governmental organisations (NGOs) in such a religious venture was also a first in Malaysian history.

The most comprehensive and impactful Islam policy in Malaysian history is to be credited to the Mahathir Administration (1981-2003), the longest serving in post-colonial Malaysian history. Mahathir's Islam policy is popularly referred to as the Islamisation policy. His Islamisation programme sought to transform the Malay-Muslim mind and attitudes to be in line with the requirements of Islam and modernity, to inculcate Islamic values in economic development and in the government machinery, and to create a national administration guided by Islam. He was also concerned with the Islamisation of Malaysian laws, but he made clear that "Islamic laws are for Muslims and meant for their personal laws, but laws of the nation, although not Islamically-based, can be used as long as they do not come into conflict with Islamic principles." 
The main goal of Mahathir's Islam policy was economic development. His political aim was 'to make Islam in Malaysia synonymous with economic progress and modernisation'. He unveiled his 'Vision 2020' which outlined his idea of an advanced nation and which also targeted 2020 as the year by which Malaysia would become an advanced nation in all respects.

After Tun Abdullah Ahmad Badawi took over power in 2003 from Mahathir he introduced a new Islam policy known as Islam Hadhari. The main reason Abdullah wanted a new Islam policy was to de-emphasise political Islam and promote Civilisational Islam that would better serve the cause of unity and progress of the Muslim community. The policy was presented as a new approach to the understanding and practice of Islam as a source of ideas and values for human and societal development particularly in the context of Malaysia as a pluralistic nation rather than as a new interpretation of the religion of Islam. The policy comprises ten principles, namely spiritual strength through faith in God, mastery of knowledge, cultural strength and independence of mind, a dynamic scientific and technological culture, a balanced and holistic economic development, good governance, social justice, protection of women and minority rights, environmental protection, and defence capability.

\section{Conclusions and Recommendations}

In April 2009, Najib succeeded Abdullah. A question commonly asked is whether or not he has an Islam policy. As yet there is no clear answer. His best known national policy is 1-Malaysia which is not an Islam policy in the sense understood here, although many aspects of it are of deep significance to Islam. He has not publicly disowned Abdullah Badawi's Islam Hadhari. In fact, within the first few months of taking office as Prime Minister he was reported on different occasions in Malaysia's main media to have affirmed his commitment to Islam Hadhari. But significantly, JAKIM (the Malaysian Department of Islamic Development), the government body usually entrusted with the task of explaining and implementing Islam policies, seems no longer concerned with Islam Hadhari. There are now signs showing that Najib is increasingly attracted to the idea of 'moderate Islam' and a 'global movement of the moderates'.

- It is extremely important for the Najib Administration not to abandon the country's Islam policy tradition since it is good for the country as a whole.

- Prime Minister Najib needs to put in place an Islam policy that would retain the best elements in previous Islam policies and that would also help to give deeper meaning and real substance to the 1-Malaysia policy. 